\title{
Pawel Kubicki
}

INSTYTUT EUROPEISTYKI

UNIWERSYTET JAGIELLOŃSKI

EMAIL: PAWEL.KUBICKI@UJ.EDU.PL

\section{POMIĘDZY PAMIĘCIĄ A HISTORIĄ. POLSKIE MIASTA WOBEC WIELOKULTUROWEGO DZIEDZICTWA}

\section{Wstęp}

W ostatnich latach można obserwować wyraźną zmianę w podejściu do wielokulturowej spuścizny polskich miast. To, co kiedyś postrzegane było jako wstydliwy balast, dziś staje się cennym zasobem. Celem niniejszego artykułu będzie próba uchwycenia mechanizmów tej zmiany i analiza procesów, które ją stymulują. W mojej analizie korzystać będę z danych uzyskanych $\mathrm{w}$ trakcie badań prowadzonych w Krakowie i we Wrocławiu w latach 2008-2009, w ramach projektu RECON Reconstituting Democracy in Europe, 6. Program Ramowy. Łącznie, w obu miastach przeprowadzono 54 wywiady pogłębiane z liderami opinii, osobami, które zarówno tworzą narrację miasta, jak też mobilizują mieszkańców do działania. Byli to przede wszystkim: samorządowcy, aktywiści NGO ukierunkowanych na działalność miejską, animatorzy i twórcy kultury, dziennikarze, blogerzy. Metoda przyjęta w projekcie badawczym odnosi się do paradygmatu antropologii interpretatywnej, rozwiniętej przez Clifforda Geertza, który pisał: „człowiek jest zwierzęciem zawieszonym w sieciach znaczeń, które sam utkał, pojmuję kulturę jako owe sieci, których analiza nie jest zatem nauką eksperymentalną poszukującą praw, lecz nauką interpretatywną poszukującą znaczenia" [2003: 36]. Stosownie zatem do jego zaleceń, analizując proces odzyskiwania pamięci o wielokulturowej przeszłości miast, należy przede wszystkim rekonstruować zmieniający się kontekst społecznokulturowy, zarówno w mikroskali, jak i makroskali. W takim przypadku autor zalecał stosowanie tzw. „gęstego opisu”, który pozwala uwzględniać nie tylko empirycznie obserwowalne zdarzenia, ale też wielowarstwową strukturę znaczeń, w ramach której konstruowane są symboliczne znaczenia miast. Powiązanie ich ze sobą w sensowną całość staje się możliwe jedynie w odniesieniu do 
konkretnego przypadku, szczególnego kontekstu kulturowego i historycznego. Dopiero wtedy można dokonywać interpretacji symbolicznego modelu świata, odtwarzania sensu, jaki ludzie przypisują swym działaniom. Jak podkreśla Geertz [2000], jest to szukanie jak ta czy inna grupa ludzi, ta czy inna epoka, ta czy inna osoba dla samej siebie tworzy sens. Zrozumienie tego sensu zwalnia badacza z rozstrzygania o prawdzie. Dlatego też w dalszej części skupiać się będę przede wszystkim opisie zmieniającego się kontekstu społeczno-kulturowego, w ramach którego dokonuje się oceny złożonego dziedzictwa miast.

\section{Wielokulturowość, pamięć i historia}

Przed przystąpieniem do zasadniczej analizy należy w pierwszej kolejności wyjaśnić stosowane w niej kluczowe pojęcia: wielokulturowość i pamięć. Obie kategorie będą stosowane w odniesieniu do miasta, którego fundamentalną cechą jest heterogeniczność, zróżnicowanie społeczne i kulturowe. Miasta zawsze przyciągały ludzi o różnych statusach społecznych, pochodzących $\mathrm{z}$ różnych kultur i wyznających różne religie. Siłą rzeczy więc, aby miasto mogło normalnie funkcjonować i rozwijać się, musiały istnieć mechanizmy współpracy i poszanowania ludzi sobie obcych. Innymi słowy, polityka wielokulturowości tworzyła się w lokalnych miejskich społeczeństwach dużo wcześniej, niż została ona oficjalnie zdefiniowana i implementowana do polityki państw. Z drugiej jednak strony, historia miast dostarcza także licznych przykładów gwałtownych konfliktów, których przyczyną była właśnie odmienność i różnorodność. Stosunek do różnorodności kulturowej miast zmienił się wyraźnie wraz z dominacją państwa narodowego, kiedy to miasta traciły swoją autonomię na rzecz dominujących polityk narodowych. Dziś, gdy idea państwa narodowego przeżywa głęboki kryzys, miasta zaczynają odzyskiwać pamięć o swojej wielokulturowej przeszłości.

W przypadku miasta idea wielokulturowości jest wpisana w jego istotę. Jednak sam termin wielokulturowość po raz pierwszy zaczął pojawiać się dopiero pod koniec lat sześćdziesiątych XX wieku w kanadyjskiej debacie nad strukturą i modelem państwa, choć początkowo odnosił się do oficjalnej dwukulturowości i dwujęzyczności Kanady [Możejko 2004: 145]. Mimo, że termin ten ostatnimi czasy święcił prawdziwe triumfy, to wciąż, jak podkreśla Andrzej Sadowski, pozostaje pojęciem nieprecyzyjnym; „Mimo wielu, nierzadko bardzo wartościowych publikacji na temat wielokulturowości, jak dotąd brak jest teorii wielokulturowości traktowanej jako zintegrowanej wewnętrznie koncep- 
cji teoretycznej. Taką teorię należałoby dopiero stworzyć” [2011: 21]. Zdaniem Sadowskiego: „Wielokulturowość jest pojęciem teoretycznym, jest określoną kategorią (koncepcją) teoretyczną, ideologią, narzędziem do badań przeobrażeń społeczeństw różnicowanych kulturowo (...). Wielokulturowość nie służy do oznaczania li tylko zjawiska (faktu) współwystępowania w określonym społeczeństwie dwóch lub więcej zbiorowości (grup) wyposażonych w autonomiczne lub odrębne kultury. Wówczas mamy do czynienia, co najwyżej, ze zróżnicowaniem kulturowym. Służy do oznaczania czegoś zasadniczo innego, nowego. Oznacza, że w społeczeństwie zróżnicowanym kulturowo na gruncie długookresowych i trwałych kontaktów międzykulturowych [odbywających się tak w sposób żywiołowy, jak i symulowany], najczęściej w ramach wspólnego obywatelstwa nastąpiła tak dalece zaawansowana integracja społeczno-kulturowa, że wytworzyło się jakościowo nowe społeczeństwo wielu kultur zdolne do realizacji wspólnych celów" [ibidem: 18-19]. Takie rozumienie polityki wielokulturowości jest użyteczne, jeśli stosujemy je do społeczeństw wykazujących się znacznym zróżnicowaniem kulturowym i społecznym, a poszanowanie i uznanie inności odbywa się w codziennych interakcjach. W przypadku polskiego społeczeństwa, które jak na współczesne standardy europejskie jest raczej homogeniczne, polityka wielokulturowości przejawia się bardziej na poziomie pamięci, niż fenomenologii życia codziennego.

Dlatego też, w przypadku polskich miast problematyka wielokulturowości siłą rzeczy przybiera specyficzne znaczenie. Do 1939 roku były one silnie zróżnicowane kulturowo, choć relacje wówczas tam panujące trudno opisać jako politykę wielokulturowości w obecnym tego słowa znaczeniu. Stosując tutaj duże uproszczenie, ówczesne stosunki pomiędzy różnymi grupami etnicznymi i religijnymi bliższe były modelowi „pluralizmu rynku ${ }^{1}$, niż polityce wielokulturowości. Po zakończeniu drugiej wojny światowej, na co wpływ miało wiele różnych czynników, miasta, które znalazły się w granicach Polski, stały się niemal bez wyjątku monokulturowe. Ponadto, z uwagi na kwestię polityczną i gospodarczą, nie doświadczyły też masowego napływu emigrantów zarobkowych, tak charakterystycznego dla drugiej połowy XX wieku w miastach Europy Zachodniej. To właśnie masowy napływ emigrantów do miast Europy Zachodniej sprawił, że kwestia wielokulturowości stała się istotna już nie tylko

Koncepcja ta odnosi się do specyficznej sytuacji pogranicza opisanej w pracach holenderskiego antropologa Johna S. Furnivalla, gdzie populacje muzułmanów, Chińczyków, Holendrów i Arabów żyły obok siebie, tworząc funkcjonalne społeczeństwo, respektując jednak granice powstrzymujące przed wzajemnym przenikaniem wzorów kulturowych. Na tej podstawie opisał on sytuację „pluralizmu rynku”, kiedy to dwie lub więcej w pełni odrębne kulturowo społeczności kontaktują się tylko przez szeroko rozumianą wymianę dóbr na rynku, a wszystkie inne płaszczyzny ich kontaktu i wymiany kulturowej oraz przenikania się kultur są zamknięte [Furnivall 1939]. 
w społeczeństwach tworzonych przez emigrantów, takich jak: Kanada, Australia czy USA, ale stała się ważnym problemem w samej Europie. W Polsce kwestia wielokulturowości przybrała odmienny charakter, nie dotyczy regulowania wzajemnych stosunków społecznych, ale pamięci zbiorowej. Polskie miasta, może z wyjątkiem Warszawy, są w porównaniu do miast Europy Zachodniej wyjątkowo homogeniczne kulturowo. Jednak specyficzna historia naszego regionu sprawiła, że w miastach tych kumuluje się dziedzictwo i pamięć wielu różnych kultur. Dlatego pisząc o stosunku do różnorodności kulturowej w polskich miastach, należy stosować raczej pojęcie pamięci zbiorowej, aniżeli polityki wielokulturowości.

Pojęcie pamięci zbiorowej ma zresztą dużo dłuższą tradycję w naukach społecznych, niż termin wielokulturowość. W dyskursie antropologicznym pojęcie to pojawiło się $\mathrm{w}$ latach dwudziestych XX wieku dzięki pracom Maurice’a Halbwachsa. Autor ten dowodził, że pamięć nie jest metaforą, ale społeczną rzeczywistością wywiedzioną z pamięci jednostek przekazywaną i podtrzymywaną przez świadomy wysiłek i grupowe instytucje: „odtwarza obraz przeszłości zgodny w każdej epoce z ideałami dominującymi w społeczeństwie" [1969: 7]. Kreowanie przeszłości zależy od obecnego kontekstu społecznego i dominujących dyskursów myślowych, które działają jak filtry odrzucające pewne treści ze wspomnień, a dopuszczające inne. Co jednak istotne dla dalszych rozważań, pojęcia pamięci zbiorowej i historii często traktowane są jako synonimy, terminów tych używa się wymiennie. Jacek Nowak, odwołując się do klasyka problemu Pierre’a Nory, podkreśla istotne różnice między tymi dwoma pojęciami. Jego zdaniem pamięć i historia nigdy nie były synonimami. Pamięć społeczna jest żywa, obecna w żyjącym społeczeństwie, ewoluująca, obecna w dialektyce przypominania i zapominania, wartościowana na różne sposoby, zdolna do przetrwania w uśpieniu - nieprzywoływana przez dłuższy czas, nagle może zostać obudzona. Historia natomiast, historia jest rekonstrukcją, zawsze problematyczną i niekompletną. Pamięć zbiorowa jest zawsze zjawiskiem teraźniejszym, wiążącym nas z teraźniejszością, a historia jest przedstawieniem przeszłości. Pamięć łączy się z grupą, w której jest zakorzeniona. Historia przeciwnie, należy do każdego i nikogo, w tym sensie jest uniwersalna. Pamięć zbiorowa jest zakorzeniona w miejscu, geście, obrazie czy obiekcie [Nowak 2011: 35]. Pamięć społeczna ma zatem charakter bardziej lokalny, jest silnie zakorzeniona w danym miejscu. Historia natomiast przybiera znamiona ideologii, jest abstrakcyjną ideą, która może się urzeczywistniać w różnych miejscach. W interesującym nas przypadku można tę koncepcję rozwinąć, dokonując rozróżnienia na pamięć społeczną miasta i historię narodu. Problem ten dość dobrze opisał 
John Gillis, twierdząc, że pamiętanie przybierało na przestrzeni dziejów trzy formy: przednarodową (do XVIII wieku), narodową (od Rewolucji Francuskiej do, mniej więcej, połowy XX wieku) oraz postnarodową. Przednarodowa historia pamięci pokazuje znaczną rozbieżność pomiędzy pamięcią elit i mas. Arystokracja, Kościół i monarchie instytucjonalizowały pamięć, masy natomiast polegały na żywej pamięci przechowywanej w ustnych przekazach, charakterystycznych dla wspólnot lokalnych. W drugiej fazie to naród stał się głównym punktem odniesienia dla pamięci i tożsamości. W tym przypadku zarówno pamięć elit i mas, jak też różnych wspólnot lokalnych stawała się wystandaryzowaną historią narodową. Współcześnie mamy do czynienia z postnarodowym okresem w wykorzystywaniu pamięci do budowy tożsamości. Autor dostrzega zjawiska desakralizacji państwa narodowego i proces demokratyzacji pamięci. Postępujące procesy globalizacji narzuciły nowe formy zbiorowej identyfikacji. Wzrosło znaczenie tożsamości międzynarodowych i globalnych z jednej strony, z drugiej natomiast uaktywniły się ruchy odtwarzające tożsamości regionalne i lokalne. W efekcie obserwujemy zjawisko mnożenia się tożsamości, zmuszające jednostki i wspólnoty do ciągłego redefiniowania swojej pozycji w zglobalizowanej przestrzeni. W sytuacji, kiedy państwa i narody tracą monopol kontroli nad pamięcią jednostek i wspólnot, to właśnie jednostki i wspólnoty lokalne tworzą alternatywne, zindywidualizowane wersje pamięci [Gillis 1994]. Podobnie argumentuje Wulf Kanstainer twierdząc, że w okresie dominacji państwa narodowego, elity wytwarzały miejsca pamięci poprzez język, pomniki i archiwa, które charakteryzował jeden cel: chronić państwo narodowe, nawet kosztem kreowania tradycji. W dobie, kiedy idea państwa narodowego ma schodzić na plan dalszy, pamiętanie zostaje już scedowane na jednostki, które mają już same dbać o zapamiętywanie przeszłości [za: Nowak 2011: 39-40]. Kwestia państwa narodowego ma tu jak widać kluczowe znaczenia. Im państwo narodowe silniejsze, tym więcej historii, która dominuje nad pluralistyczną pamięcią.

Od końca XX wieku narasta szereg procesów, które w sposób zasadniczy osłabiają pozycję państwa narodowego: integracja ponadnarodowa, renesans ruchów etnicznych i regionalnych, globalizacja, intensyfikacja procesów migracyjnych, rozwój mediów globalnych, zwłaszcza Internetu i wiele innych. Wszystkie te procesy, w różnym zakresie i z różną intensywnością, osłabiają państwo narodowe, które traci swój dotychczasowy monopol na kontrolę i reprodukcję kultury. W dużym uproszczeniu można powiedzieć, że wystandaryzowana i zideologizowana historia narodowa zaczyna przegrywać z pluralistyczną i demokratyczną pamięcią miast. Kraków i Wrocław stanowią interesujące przykłady tego procesu. Oba miasta w szczytowym okresie rozwoju 
idei państwa narodowego poddane były intensywnym procesom nacjonalizacji przestrzeni. Naród jako byt abstrakcyjny potrzebuje materialnych desygnatów, symboli, za pomocą których może zostać wyobrażony, zmaterializowany. Miasto, $\mathrm{z}$ jego historyczną tkanką i odpowiednio zinterpretowaną historią, stawało się dobrym materiałem na symbol narodowy.

\section{Nacjonalizacja przestrzeni miejskich}

Kraków stanowi jeden $\mathrm{z}$ najważniejszy polskich symboli narodowych. Mimo, że w tysiącletniej historii państwa polskiego zawsze odgrywał wiodącą rolę, to jego symboliczne znaczenia dla kultury narodowej ukształtowały się na przełomie XIX i XX wieku. Miasto w tym czasie znalazło się w wyjątkowej sytuacji. Od końca lat sześćdziesiątych XIX wieku polityka zaborcza Prus i Rosji stała się coraz bardziej restrykcyjna, wzmagały się represje wobec polskiej idei narodowej. W tym samym czasie w Galicji nastąpił zupełnie odwrotny proces, rozpoczyna się okres tzw. autonomii galicyjskiej, liberalizacji polityki austriackich zaborców. W sytuacji, gdy na pozostałych ziemiach polskich wzmagał się proces rusyfikacji i germanizacji, w Galicji istniały dogodne warunki dla rozwoju polskiej kultury i tożsamości narodowej. Kraków, jako była stolica, miejsce koronacji i pochówku polskich monarchów, posiadał wszelkie atrybuty do stawania się centralnym symbolem polskiej idei narodowej nieistniejącego państwa. Stosownie do wymogów epoki, rytuałami, które miały decydujące znaczenie dla kształtowania się narracji Krakowa, były przede wszystkim pogrzeby bohaterów narodowych. W stosunkowo krótkim czasie ukonstytuowały się dwa Panteony narodowe: Katedra wawelska i kościół na Skałce, jako miejsca pochówku bohaterów narodowych. Skala oddziaływanie Panteonów narodowych, przy niewielkiej przestrzeni ówczesnego Krakowa sprawiała, iż symbolika "grobu ojczyzny” zdominowała zupełnie ówczesne narracje miasta, tworząc z całej tkanki miasta prawdziwe sacrum narodowe. Długo można by wyliczać utwory literacki, publicystyczne i naukowe, które stworzyły kanonicze ramy interpretacyjne symboliki miasta, zgodnie z którymi Kraków jest postrzegany przede wszystkim jako polski symbol narodowy, mimo, iż podobnie jak cała Galicja, był on miastem mocno zróżnicowanym pod względem etnicznym i religijnym. W ogromie materiału $\mathrm{z}$ tego okresu niemal zupełnie są pomijane kwestie zróżnicowania kulturowego miasta, Kraków był na wskroś polski [Kubicki 2010]. 
Wrocław także został poddany intensywnym procesom nacjonalizacji przestrzeni, choć, co zrozumiałe, procesy te przebiegały inaczej niż w Krakowie. W tym przypadku miasto stało się zakładnikiem dwóch silnych idei narodowych, najpierw niemieckiej, a później polskiej. Powstanie nowego państwa niemieckiego pod koniec XIX wieku wymagało stworzenia wspólnej niemieckiej symboliki. W związku z tym nastąpiła intensywna produkcja takich symboli, w dużej mierze związanej ze zniemczaniem przestrzeni miast, co opisał Eric Hobsbawm [2008] na przykładzie prawdziwej pomnikomanii, która ogarnęła niemieckie miasta przełomu XIX i XX wieku. Proces ten dotyczył także Wrocławia. Jego złożona, środkowoeuropejska historia, oparta na dynastycznych tradycjach piastowskich, luksemburskich czy habsburskich została zastąpiona przez historię etniczną - niemiecką. Historia Wrocławia została napisana przez niemieckich historyków, z niemieckocentrycznego punktu widzenia, dla którego w owym czasie brakowało alternatywnych wizji. Kiedy po 1945 roku Wrocław znalazł się w granicach Polski, jak pisze Georg Thum; „nie istniały żadne źródła historiograficzne, do których osadnicy mogliby po prostu sięgnąć. Historia Wrocławia był dotąd pisana przez Niemców (...) autorzy (...) skupiali się na tym aby uwypuklić rzekomo niemiecką istotę tego miasta. Ponieważ to germanocentryczne ujęcie dziejów Wrocławia nie mogło zaoferować polskim osadnikom żadnych punktów odniesienia, jego historię musiano po 1945 roku pisać od nowa" [2005: 257]. Po 1945 roku Polacy zmuszeni byli do pisania od podstaw zupełnie nowej historii miasta. Nowa historia Wrocławia i tym razem była silnie naznaczona przez ideologię narodową i pisana w ramach jednego dyskursu etnicznego, tym razem polskiego. W tym przypadku szczególnie akcentowano tradycję piastowską, która dobrze pasowała do nowego modelu państwa polskiego opartego na homogeniczności etnicznej i micie „odwiecznych” zmagań polsko-niemieckich. Ponadto, niemal wszyscy nowi osadnicy musieli się zmagać z podwójną obcością miasta: strukturalną i kulturową. Strukturalną, gdyż w ogromnej większości pochodzili z terenów wiejskich i małomiasteczkowych. Kulturową, gdyż Wrocław do 1945 roku był miastem na wskroś niemieckim, opisywanym i definiowanym przez Niemców i dla Niemców. Dlatego też nowi mieszkańcy rekonstruując swoją tożsamość, poszukiwali jej raczej w swojskiej historii narodowej, niż w obcej im pamięci miasta. Polonizowali zatem materialną i kulturową przestrzeń Wrocławia, i to nie tylko zgodnie $\mathrm{z}$ wymogami komunistycznej propagandy, ale przede wszystkim po to, aby oswoić obce im miasto. 


\section{Rekonstrukcja pamięci miast}

Stosunek do wielokulturowej pamięci miast zaczął się mocno zmieniać w ostatniej dekadzie. Mimo, że w obu miastach daje się zauważyć silną lokalną specyfikę [por. Galent, Kubicki 2010], z uwagi na ograniczone rozmiary artykułu, dalej skupię się jedynie na cechach wspólnych, zaobserwowanych w trakcie badań prawidłowościach. Jednym z kluczowych czynników zmiany jest akcesja Polski do Unii Europejskiej i zmiana podstaw gospodarczych Krakowa i Wrocławia. Oba miasta stają się ważnymi centrami gospodarki kreatywnej, oba też wyjątkowo korzystają na idei swobodnych przepływów w ramach Unii Europejskiej. Przykładem takich działań jest turystyka, stanowiąca we współczesnej gospodarce jedną z najważniejszych gałęzi przemysłu. Kraków i Wrocław to jedne $\mathrm{z}$ najchętniej odwiedzanych polskich miast, $\mathrm{z}$ bardzo rozbudowanym „przemysłem” promocji zewnętrznej. Widać tutaj istotną prawidłowość. Jednym z najlepszych sposobów zachęcania turystów do przyjazdu jest tworzenie wizerunku miasta wyjątkowego, otwartego i tolerancyjnego, a to można osiągnąć w sposób najbardziej efektywny poprzez odwołanie się do wielokulturowego dziedzictwa miasta. Dlatego też w przypadku obu miast, na pierwszy plan wysuwa się dziś wielokulturowe dziedzictwo, które jeszcze do niedawna wypierane było przez ideologię narodową. W przypadku Krakowa z dumą eksponuje się żydowskie tradycje Kazimierza. Dzielnica² ta przed wybuchem drugiej wojny światowej zamieszkana była głównie przez krakowskich Żydów. Po wojnie, na skutek Holokaustu, Kazimierz został niemal zupełnie wyludniony. Z czasem, w epoce PRL-u, powstało tam swoiste getto biedy i marginesu społecznego. Jednak od połowy lat dziewięćdziesiątych sytuacja zaczęła się zmieniać. Pojawiały się inicjatywy związane z dziedzictwem żydowskim; Festiwal Kultury Żydowskiej zyskiwał coraz większą popularność, otwierano restauracje i kawiarnie stylizowane na tradycje żydowskie. Obecnie stanowi jedną z najmodniejszych dzielnic Krakowa, bardzo chętnie odwiedzanych zarówno przez mieszkańców miasta, jak też turystów.

Wrocław ze swoim oficjalnym hasłem promocyjnym: „Wrocław - miasto spotkań”, silnie podkreśla wielokulturową przeszłość miasta. W tym celu także podjęto próbę rewitalizacji ${ }^{3}$ kwartału „dzielnicy wzajemnego szacunku”, częstej jednak nazywanej „dzielnicą czterech wyznań”, gdzie na niewielkiej

2 Nazwa dzielnica używana jest tutaj w znaczeniu odrębnej przestrzeni społeczno-kulturowej, gdyż Kazimierz nie stanowi odrębnej jednostki administracyjnej.

3 Należy tu poczynić pewne zastrzeżenia. Pojęcie rewitalizacji oficjalnie stosowane przez władze miasta, ma jednak niewiele wspólnego z tym, jak termin ten rozumie się na gruncie socjologii. Działania władz Wrocławia w tej przestrzeni miejskiej lepiej opisuje termin gentryfikacji. 
przestrzeni sąsiadują ze sobą: kościół ewangelicko-augsburski, kościół rzymsko-katolicki, cerkiew i synagoga. W zamyśle władz dzielnica ta miałby się stać symbolem całego Wrocławia, gdzie w duchu tolerancji i wzajemnego poszanowania spotyka się wiele różnych kultur. $\mathrm{W}$ praktyce udaje się to $\mathrm{z}$ różnym skutkiem.

Dla idei wielokulturowości we Wrocławiu szczególne znaczenie miała książka Mikrokosmos. Historia miasta środkowoeuropejskiego, napisana przez Normana Daviesa, który dał w niej nową wykładnię dla narracji miasta. Przełamał dotychczasową dychotomię myślenia o Wrocławiu: polski versus niemiecki. Autor podkreślił, że w swojej niemal tysiącletniej historii miasto wielokrotnie zmieniało przynależność państwową. Co istotne jednak, niemal za każdym razem zmiana granic politycznych pociągała za sobą także zmianę nazwy miasta - kluczową dla jego tożsamości; od piastowskiego Wrotizla, przez czeski Vretslav, austriacki Presslaw, pruski i niemiecki Breslau, kończąc na współczesnym Wrocławiu [Davies, Moorhouse 2002]. Taka interpretacja pozwoliła dowartościować lokalną pamięć miasta, przełamać myślenie w kategoriach ideologii narodowych, które tę pamięć zawłaszczały.

Idea wielokulturowości miast wykorzystywana jest przez oba miasta także w celu przyciągania kapitału inwestycyjnego. Współczesna gospodarka oparta na wiedzy i kulturze, potrzebuje specyficznego kapitału - kapitału kreatywnego oraz twórczych jednostek miasta, które konkurują o taki kapitał, muszą budować wizerunek otwartego i tolerancyjnego. W tym przypadku odwoływanie się do wielokulturowego dziedzictwa miasta tworzy czytelny przekaz, że w takim miejscu szanuje się różnorodność. Ma to istotne znaczenie, gdyż środowisko kreatywne wymaga tolerancji i uznania dla niestandardowych zachowań. Tezę taką udowadniał, w tyleż popularnej, co kontrowersyjnej książce Narodziny klasy kreatywnej Richard Florida. Udowadniał on, jak ważną rolę dla współczesnej gospodarki odgrywa „potęga miejsca”. Niektóre miasta dzięki swojej atrakcyjności wynikającej z jakości życia, różnorodności i tolerancji są w stanie przyciągać najbardziej kreatywny kapitał ludzki [Florida 2010: 221240]. Wielokulturowość i tolerancja stają się tym samym dobrami, które można wymieniać na realny wzrost poziomu życia i dochodów, stają się warunkiem efektywnego rozwoju miasta we współczesnej gospodarce opartej na wiedzy i kulturze.

Zarówno Kraków, jak i Wrocław to przykłady miast, które jak na polskie warunki, znakomicie poradziły sobie w nowej rzeczywistości. Dzięki mechanizmom przyciągania twórczych jednostek, oba miasta osiągają spektakularny sukces w porównaniu do innych polskich miast. Co charakterystyczne, wśród wszystkich respondentów idea wielokulturowości była absolutnie niekwestio- 
nowana, choć bardziej wskazywali oni na jej marketingowy wymiar, niż na codzienną rzeczywistość miejską. Interesujące w tym kontekście są wnioski z badań prowadzonych przez Katarzynę Sztop-Rutkowską nad problemem historii i pamięci w społecznościach Białegostoku i Lublina. Autorka podkreśla wyjątkowo słabą pamięć o żydowskich tradycjach tych miast, częste strategie wypierania i filtrowanie pamięci. Jak pisze Sztop-Rutkowska: „Pamięć o Zagładzie, o żydowskich mieszkańcach Białegostoku i Lublina oraz o Polakach pomagających Żydom w czasie Szoa należy wciąż w większym stopniu do tzw. pamięci pasywnej uśpionej czy też używając sformułowania A. Assmann magazynującej. Oznacza to, że pamięć w tych zasobach ma charakter potencjalny, nie podlega bowiem wciąż dyskusji, nie jest też powszechnie upamiętniana, jak również nie jest istotnym elementem miejsc pamięci mieszkańców miasta. Z badań wynika, że pamięć o Żydach nie jest wciąż pamięcią komunikatywną na poziomie przekazu rodzinnego, jest bowiem związana bardzo silnie $\mathrm{z}$ traumą świadków, być może również z poczuciem winy. Jest to wciąż w prywatnym dyskursie temat sepizowany, tabuizowany" [2011: 79]. Sytuacja taka zdaje się potwierdzać opisane powyżej mechanizmy powrotu dyskursu wielokulturowego. Białystok i Lublin to miasta, które nie są jeszcze włączane z taką intensywnością w europejską sieć miast, jak Kraków i Wrocław. Kwestia turystyki i nowej gospodarki nie odgrywa tam aż tak istotnej roli. Stąd też, mimo, że podobnie jak w Krakowie i Wrocławiu, idea wielokulturowości także i tam została wprzęgnięta w marketingowe tryby, to w niewielkim stopniu przekłada się jeszcze na dochody miasta i wzrost jakości życia.

Powrót do wielokulturowej pamięci miast jest zatem uwarunkowany w dużej mierze racjonalną kalkulacją bilansu zysków i strat. Mieszkańcy miast coraz bardziej zdają sobie sprawę z faktu, że otwartość i tolerancja stanowi warunek konieczny dla efektywnego rozwoju miasta we współczesnej gospodarce z dominującą rolą miast kreatywnych. Jednak, aby takie postawy mogły się upowszechniać konieczne jest tworzenie się nowych tożsamości społecznych. W Polsce, $\mathrm{z}$ uwagi na cały szereg różnych czynników, dominującym wzorem kulturowym był etniczny model tożsamości narodowej. Jedną z konsekwencji tego stanu rzeczy było to, że polskie społeczeństwo przyjmowało cechy charakterystyczne dla społeczeństwa zamkniętego, które zgodnie z teorią Karla Poppera [1993], charakteryzuje się: brakiem racjonalnej debaty politycznej, interwencjonizmem państwa, myśleniem w kategoriach autorytarnych dogmatów, ksenofobią, brakiem autotelicznych związków, a zwłaszcza brakiem zdrowego współzawodnictwa o miejsce w strukturze społecznej. Obecnie zachodzi intensywny proces „otwierania” polskiego społeczeństwa. Dzieje się tak dlatego, że 
bardzo intensywnie, zwłaszcza w dużych metropoliach, rozwija się tzw. nowe mieszczaństwo [Kubicki 2011].

Nowi mieszczanie mają niewiele wspólnego z klasycznymi wyobrażeniami klasy mieszczańskiej ukształtowanymi w XIX wieku. Dla opisania specyfiki tworzenia się polskiego mieszczaństwa używam przymiotnika „nowi” z dwóch głównych powodów. Po pierwsze, z uwagi na fakt słabości i obcości kulturowej mieszczaństwa w polskiej kulturze narodowej. Po drugie, w epoce globalizacji, dominacji społeczeństwa sieci i gospodarki postfordowskiej samo pojęcie „mieszczaństwo”, rozumiane jako dominująca grupa w przestrzeni miejskiej, wymaga redefinicji. W polskich miastach dorastają kolejne pokolenia wychowane i socjalizowane w miejskiej kulturze, które, jak każdy nowy fenomen społeczny, poszukuje nowych narracji, na bazie których może konstruować swoją tożsamość. Dzieje się także dlatego, że ostatnia dekada to czas głębokich zmian w społeczno-kulturowej przestrzeni miast. W pełnię dorosłego życia wchodzi ostatni wyż demograficzny z przełomu lat siedemdziesiątych i osiemdziesiątych. Co charakterystyczne, na skutek dynamicznego rozwoju szkolnictwa wyższego, znakomita większość przedstawicieli tego wyżu swoje życie związała z dużymi miastami. W porównaniu do połowy lat dziewięćdziesiątych ubiegłego wieku, liczba studentów wzrosła aż pięciokrotnie. W szczytowym roku 2005/06, według danych GUS-u, liczba studentów w Polsce wynosiła 1953 tysięcy osób, podczas, gdy 10 lat wcześniej liczba ta nieznaczenie przekraczała 500 tysięcy. Jednym ze skutków tak gwałtownego wzrostu liczby studentów w Polsce była masowa migracja młodych ludzi z szeroko rozumianej prowincji do miast akademickich. Dla przykładu, tylko w dwóch największych ośrodkach akademickich (Warszawa 280 tysięcy, Kraków 190 tysięcy) studiuje dziś więcej osób niż w całej Polsce w początkach lat dziewięćdziesiątych. Pokolenie wyżu demograficznego i boomu edukacyjnego jest też pokoleniem integracji europejskiej. Jako pierwsze w pełni doświadczyło dobrodziejstw swobody przepływów: studiowania na zagranicznych uczelniach, pracy w międzynarodowym środowisku, swobody podróżowania. Dominują zatem nad starszymi pokoleniami jakością wykształcenia, znajomością języków, otwartością i obyciem, co w zasadniczy sposób wpływa na wzmacnianie kapitału kulturowego i społecznego.

Wszystko to, w połączeniu z coraz większym kapitałem ekonomicznym bogacącej się miejskiej klasy średniej sprawia, że wielokulturowa przeszłość miast nie wzbudza już lęków, nie jest wstydliwie wypierana z pamięci. Co więcej, różnorodność traktowana jest jako inspiracja, a wielokulturowa przeszłość miast jako powód do dumy. Skutkiem tego są silne procesy zmierzające do redefiniowania tradycyjnych tożsamości. W największym skrócie, procesy te odnoszą 
się do przełamywania dominującego dotychczas monokulturowego dyskursu, który zbudowany był na micie homogeniczności etnicznej i religijnej polskiego społeczeństwa. Nowi mieszczanie poprzez szereg różnych inicjatyw, głównie ze sfery NGO, odkrywają i waloryzują wielokulturowe dziedzictwa miast, akcentując przy tym otwartość i tolerancję dla wszelkiej „inności”, wiedząc, że stanowi to warunek konieczny dla efektywnego rozwoju miast.

\section{Podsumowanie}

Wielokulturowa przeszłość miast przestaje być już wstydliwym bagażem; jest coraz częściej postrzegana jako cenny zasób i wartość. Wpływ na tę zmianę ma wiele czynników, często współzależnych. Im bardziej miasto włączane jest w europejską sieć wymiany, tym bardziej pozytywny jest stosunek do wielokulturowej przeszłości miasta. Wiąże się to $\mathrm{z}$ faktem, iż usieciowienie przekłada się na wzmacnianie kapitałów: kulturowego, społecznego i ekonomicznego. To z kolei sprzyja wyższej samoocenie, dodaje pewności siebie, w tej sytuacji „inny” nie wzbudza już lęku, staje się partnerem. Idea wielokulturowości została także wykorzystana do pragmatycznej gry rynkowej i daje się przełożyć na wymierne korzyści, zwiększa atrakcyjność miasta, przyciąga turystów i inwestorów. Wszystko to możliwe jest także dlatego, że w miastach dorastają kolejne pokolenia silnie identyfikujące się z kulturą miejską, której istotą jest różnorodność. Skutkiem tego zmienia się także dominujący wzór polskiej kultury narodowej, z modelu etnicznego i zamkniętego ewoluuje w kierunku obywatelskiego i pluralistycznego.

\section{Bibliografia:}

Davies N., Moorhouse R. [2002] Mikrokosmos. Portret miasta środkowoeuropejskiego: Vratislavia - Breslau - Wrocław, Kraków

Florida R. [2010] Narodziny klasy kreatywnej, Warszawa

Furnivall J. S. [1939] Netherlands India: A Study of Plural Economy, Cambridge

Galent M., Kubicki P. [2010] An Invisible revolution. How the urban way of life is transforming the identities of Poles, [w:] M. Góra, Z. Mach (red.), Collective identity and Democracy. The Impact of EU Enlargement, Oslo

Geertz C. [2003] Opis gesty - w stronę interpretatywnej teorii kultury, [w:] M. Kempny, E. Nowicka (red.), Badanie kultury. Elementy teorii antropologicznej, Warszawa 
Gillis J. (red.), [1994] Commemorations: The Politics of National Identity, Princeton

Halbwachs M. [1969] Społeczne ramy pamięci, Warszawa

Hobsbawm E. [2008] Masowa produkcja tradycji: Europa, lata 1870-1914, [w:] E. Hobsbawm,

T. Ranger (red.), Tradycja wynaleziona, Kraków

Kubicki P. [2011] Nowi mieszczanie w nowej Polsce, Warszawa

Kubicki P. [2010] Miasto w sieci znaczeń. Kraków i jego tożsamości, Kraków

Możejko E. [2004] Wielka szansa czy iluzja: wielokulturowość $w$ dobie ponowoczesności, [w:] W. Kalaga (red.), Dylematy wielokulturowości, Kraków

Nowak J. [2011] Społeczne reguly pamiętania. Antropologia pamięci zbiorowej, Kraków

Popper K. [1993] Społeczeństwo otwarte i jego wrogowie, Warszawa

Sadowski A. [2011] Socjologia wielokulturowości jako nowa subdyscyplina socjologiczna, „Pogranicze. Studia Społeczne” t. 18

Sztop-Rutkowska K. [2011] Niepamiętane historie miasta. Żydowska przeszłość Białegostoku i Lublina w [nie]pamięci obecnych mieszkańców, „Pogranicze. Studia Społeczne” t. 18

Thum G. [2005] Obce miasto. Wrocław 1945 i potem, Wrocław 


\section{SUMMARY}

\section{Between memory and history. Polish cities and their multicultural heritage}

This article discusses the question of the reconstruction of social memory in Polish cities. To illustrate this process the author decided to employ a comparative approach and analyzed this process in two Polish cities: Krakow and Wroclaw. The case selection was directed by their comparable population size and their importance as cultural and scientific centres. As far as differences between the three are concerned, their demographic reproduction patterns are substantially distinct. Krakow has preserved and reproduced its traditional bourgeois character, whereas Wroclaw serves as a typical example of a post-migrant city with an entirely reconstructed identity because of the post-World War II population shifts. Despite their multiethnic composition and heritage, in the formative period for contemporary collective identities in the 19th century these cities built their identities solely with relation to symbolically homogenous contexts (Polish in Krakow and German in Wroclaw). These nationally homogeneous discourses were even strengthened during the postwar period and continued long after WWII. The breakthrough came with the collapse of communism. The inhabitants of the cities regained a possibility of social agency and by this token a chance for building new identities. However, these processes did not start from scratch. They were determined by existing social and cultural structures which imprinted their particular patterns on their new developments.

\section{Keywords:}

city, identity, Krakow, multiculturalism, social memory, Wroclaw 